\title{
Visual Analysis of Real Estate Investment Trusts Research-A Bibliometric Analysis Based on CiteSpace III
}

\author{
Wenhao Meng*, Kunchang Shen, Qiao An \\ School of Government, Beijing Normal University, Beijing, China \\ Email: "mwh0529@163.com
}

Received 25 November 2015; accepted 18 December 2015; published 21 December 2015

Copyright (C) 2015 by authors and Scientific Research Publishing Inc.

This work is licensed under the Creative Commons Attribution International License (CC BY). http://creativecommons.org/licenses/by/4.0/ c) (i) Open Access

\begin{abstract}
As an income-based real estate asset securitization innovation born in 1960s, real estate investment trusts now have grown into the fourth important assets allocation choice behind stocks, bonds and cash in the US. With the status of REITs is rising in the investment decisions, the research literature about REITs is increasing either. In order to sort out this research literature effectively, this paper uses the visualization software CiteSpace to analyze the journal articles and references of REITs, which have been embodied by the web of science core collection. Also, this paper attempts to describe the development network and cooperation characteristics in REITs research field, at the same time, we expect this paper can provide ideas and evidence for academia to research REITs further.
\end{abstract}

Keywords

CiteSpace III, Cooperation Characteristics, Key Literature, REITs

\section{Introduction}

In July 2015, Penghua Qianhai Vanke REITs became the first Chinese public offering real estate investment trusts to list and trading on the Shenzhen stock exchange with the ticker of 160,041. These REITs have sold out 3 billion yuan share in shortly 4 days [1]. This phenomenon drives real estate sector and financial sector people's high attention including myself. REIT is a way of trust investment that focuses on equity and mortgage in real estate business. At the beginning, it runs more like an investing fund, but, gradually it becomes to a special real estate corporation. Comparing to other investments like stocks or bonds, REITs are strong income ve-

*Corresponding author.

How to cite this paper: Meng, W.H., Shen, K.C. and An, Q. (2015) Visual Analysis of Real Estate Investment Trusts Research-A Bibliometric Analysis Based on CiteSpace III. American Journal of Industrial and Business Management, 5, 794805. http://dx.doi.org/10.4236/ajibm.2015.512076 
hicles, because REITs must pay out at least 90 percent of their taxable income in the form of dividends to shareholders. Also, REITs have other advantages over these investments like lower risk and lacks of fluctuation [2].

The United States is the oldest and the most experienced country to operate REITs in the world. REITs were created in the United States when President Dwight D. Eisenhower signed into law the REIT Act title contained in the Cigar Excise Tax Extension of 1960. But, after ten years of the Act released, there are only 10 REITs in whole United States [3]. After a germination period of development in 1960s, REITs market began to fall into bubble crisis in 1970s and early 1980s. At the end of 1979, the scale of REITs, which was measured by the total capital value of equal market, was smaller than the corresponding size of the end of 1972. The main reason was that the entire stock and the trust investment market had plunged into chaos because of the big inflation in 1970s. Naturally, the REITs inevitably sank into despair.

After the miserable period of bubble and low tide in the 70s and early 80s, the Tax Reform Act of 1986 became a turning point for recovery of American REITs. This Act lowered the entry criteria of real estate investment trusts and from that time, REITs was not only could own real estate but also could manage real estate under certain conditions. Since then, American REITs stride into the fast developing period. The total amount of money that raised in the public offering in 1993 had exceeded the total amount in the last thirteen years. Nowadays, REITs listed in the stock exchange of more than 30 countries (regions) which included Japan, Korea, Singapore and Australia, and its size had been increased from the $\$ 8.9$ billion in 1990 to $\$ 1.8$ trillion by the end of March 2015 (Global News, finance. huanqiu.com).

The academic focus on REITs had already started in 1960s, but it was just sporadic and intermittent research. Until 1990s, REITs researchers started diving into REITs study. Web of science core collection included as many as 84 articles of the REITs field in 2013 alone, which were even more than the sum number of the articles before 1990. Taken together, the present study of REITs could be separated into two areas. The first part belonged to the issue of IPO. Research in this aspect focused primarily on the contrast between REITs' IPO and other operating company's IPO or initial released price problem of REITs' IPO. The second part focused on the rate of return of REITs and the similarities and differences between REITs and other investment products such as bonds, stocks and so on.

Although there are a large number of research findings. We still lack of sufficient understanding for the research characteristics and trend of development of REITs research. Also, it's hard for us to know how to promote the REITs study one step further (There is no article that belongs to review or bibliometrics of REITs in Web of Science Core Collection). As Christopher Dyer said, on one hand, economic history is an entertaining aspect of business, on the other hand, it provides us the key to understanding those fundamental process of change, and reveals the great truths of the human condition for us [4]. Analyzing and sorting out the previous literature, it's sort of like standing on the shoulders of giants to look out the whole world. Therefore, this article tries to summarize the characteristics of REITs study with bibliometric approach. To summarize the characteristic of the article numbers, to find the feature of co-cited references, and then with the visual analysis method to find the knowledge base and key literature of REITs research, this is what this article aim at. Also, we expect this paper could provide ideas and evidence for future scholars to do better research of REITs.

\section{Methods}

The research methods of this article belong to the visualize bibliometric methods. Visual information retrieval is a new research field that combines information retrieval and information visualization study together. This method shows us a new type of information research, which put the users experience in first place. Visual information systems not only give users an intuitive feeling in research, but also, it totally changed the retrieval process into an exploratory and fun activity [5]. Bibliometric study began in the mid-20th century, and, the word bibliometrics was raised by the famous British intelligence experts Alan Pritchard in his paper statistical bibliography, an interim bibliography, clearing house for federal scientific and technical information in 1969 [6].

After decades of development, bibliometric analysis has already become an objective and quantitative tool that could reveal the laws of development in the academic research. As for the focus field, bibliometric analysis has been extended from physics, biology, and medicine to the field of economic research, management, etc. Through the analysis of the literature information including titles, keywords, authors, journals, published year, document contents and citation information etc., bibliometric analysis could reveal us the history of the subject development, research priorities and future directions in a quantitative way. Currently, bibliometric analysis has 
been seen as an important tool that only could summarize the past results of study, but also give us a hint to reveal future research trends.

We use EndNote as the reference management statistical tool in this article, which provides researchers with quick, powerful access to the world's leading citation databases. It has authoritative, multidisciplinary content covers over 12,000 of the highest impact journals worldwide. With EndNote, researchers can manage hundreds of thousands of references in doing research. As the SCI (Thomson Scientific Company) official software, EndNote plays an important role in the field of Biblio-metrological Analysis. In this article, we use Endnote to analyze literatures quantitative characteristics, cooperation characteristics, analyze the source of the citation journals.

This article analyzed the data based on the visual analysis software CiteSpace III. CiteSpace is a visual information analysis software based on the JAVA platform, and the CiteSpace III we mentioned above is the third version of it, which were developed by Professor Chaomei Chen from Drexel University in Philadelphia. As one of the most advanced software of bibliometric analysis, CiteSpace is so unique, because with its help consumers (researchers) could get a knowledge map shows trends of subjects. Not only this, CiteSpace also could help researchers acquire the development of a certain subject, form the research origin to the frontier [7]. In 2012, Chaomei Chen and his colleagues did visual analysis for the emerging field of regenerative medicine research trends by using CiteSpace. In this paper, Chaomei Chen asserted that Yamanaka's paper has unparalleled outstanding performance than other papers based on the reference citation performance [8]. Also, they believeded Yamanaka has authority status experts in the Regenerative medicine field. And Chaomei Chen's words turned to be right in the same year (2012). Shinya Yamanaka was awarded the Nobel Prize in Physiology or Medicine Prize in 2012.

We choose web of science core collection as our literature source. After a strict selection, Web of Science Core Collection now has more than 10,000 authoritative, high-impact academic journals worldwide. More than that, 110,000 international conferences papers were included too, covering scientific area from natural science, engineering and technology, biomedical, social science, to other subject like arts and humanities (Thomson Reuters http://www.thomsonscientific.com.cn/productraining/WOS/). From time line view, the first paper were included by web science could dating back to 1900 . That is why this article regards papers collected by Web of Science Core Collection database as our research object. With its help, we could develop the scientific search strategy, and further more to carry out related research.

In order to ensure the effectiveness of visualization analysis, CiteSpace requires the users to "use words as widely as possible to describe or identify a field of knowledge, and this requirement aims at ensuring that the following analysis could covers an area the entire contents of knowledge". For instance, if we only choose the word REITs as the key word to develop our research, we may neglect the articles titled by REIT. Therefore, In the keywords searching part, in order to make sure that we could gather all the relative search results, we choose REIT and REITs as the keywords to carry out the research.(data collect time: 2015.11.15) The results shows as Table 1.

As shown in Table 1, with an integrated search method, we received a total number of 961 articles. But, there are many repeat articles in these 961 articles. With the duplication function of EndNote, we found that there are 259 articles were repeated in the total number. Remove the 259 duplicate articles; we gathered 702 articles as a result. These 702 articles provide the basis for this paper, and with its help, this paper spreads out from the following aspects: quantitative characteristic numbers, main journals in REITs research, cooperation characteristic in developing REITs research, and key nodes literatures in REITs development.

\section{Research Characteristics Analysis}

\subsection{Quantitative Characteristics}

Analyzing quantitative characteristics of REITs literature mainly spread out from two aspects: the literature written time perspective, and main journals of REITs study perspective. In these 702 articles, we have been re-

\section{Table 1. Search terms and search results.}

\begin{tabular}{ccc}
\hline Search Term & Results \\
\hline REITs & 491 \\
REIT & 470 \\
\hline
\end{tabular}


trieved from the WOS Core Collection database, the earliest paper is Value of cotton and jute flour bags in reducing infestation by the hairy spider beetle, ptinus-villager (REIITs) written in 1958 by Watters F. L. [9]. While, the lasted updated article is Leverage and Returns: A Cross-Country Analysis of Public Real Estate Markets by Giacomini, E., which was published on the journal named Journal of real estate finance and economics in August 2015. [10].

From 1956-1970, this whole fifteen years, only six articles of REITs field were included by the web of science core collection. This situation is consistent with the view that REITs was suffering negligence in the 1960s United States investment markets. Although, the "Real Estate Investment Trust Act" has been approved by the US Congress in 1960, the reaction of invest market was nearly muted in its first ten years. That means in its first 10 years, REITs was increased really slowly. By the end of 1973, there are only 53 REITs in the US market. But, Things were changed until 1986. In this year, the "Tax Reform Act" was approved by the United States congress, which started the REITs regulation reform from the two aspects. The first change is US government started to allow REITs companies not only can own real estates, but also could directly carry out the operation and management of real estate projects to provide the service for its customers. The second change was the reform of REITs taxes. US government canceled the rules that investors could remedy his operation loss by not paying taxes. It was from that year that REITs start its rapidly development.

As what was shown in Figure 1, research findings of REITs had a significantly increase from the beginning of 1986. By the time sector of 1991-1995, articles of REITs in Web of Science has reached an average annual 10 per year.

Since 1998, the literature numbers in WOS Core Collection has reached an average 20 articles per year. This is because at the end of 20th century, REITs was expanded to countries like Japan, Singapore, South Korea and other Asian countries. REITs study began extended from American and Europe to Asia. In recent 25 years of development, with the improvement of the REIT status in the capital markets and the countries that developed REITs expanded, the academic study of REITs had continued to increase. As what was shown in Figure 1, REITs literature increased from average annual 20 per year in1996-2000 to more than 46 per year in 2011-2015, the increase ratio was nearly 130\% (2015 statistical data has not been completed yet, but its growth trend can be judged from the trend line we drawn).

In order to do more careful observation for the study progress of the past 10 years, it is necessary to describe the quantitative characteristic of recent ten years. The statistical results are shown in Figure 2.

In order to study the literature's quantitative changes in recent 10 years more precisely, we added the logarithmic trend line on the basis of the histogram in Figure 2. The reason why we choose the logarithmic trend line is depend on data situation. Logarithmic trend line is the best fit curve for the situation that the magnitude of data changes quickly in a very short period of time. Statistical results shown in Figure 2 shows that logarithmic trend line rises steadily. That reveals there was a steady increase in REITs research over the past decade, but there is no breakthrough in last ten years.

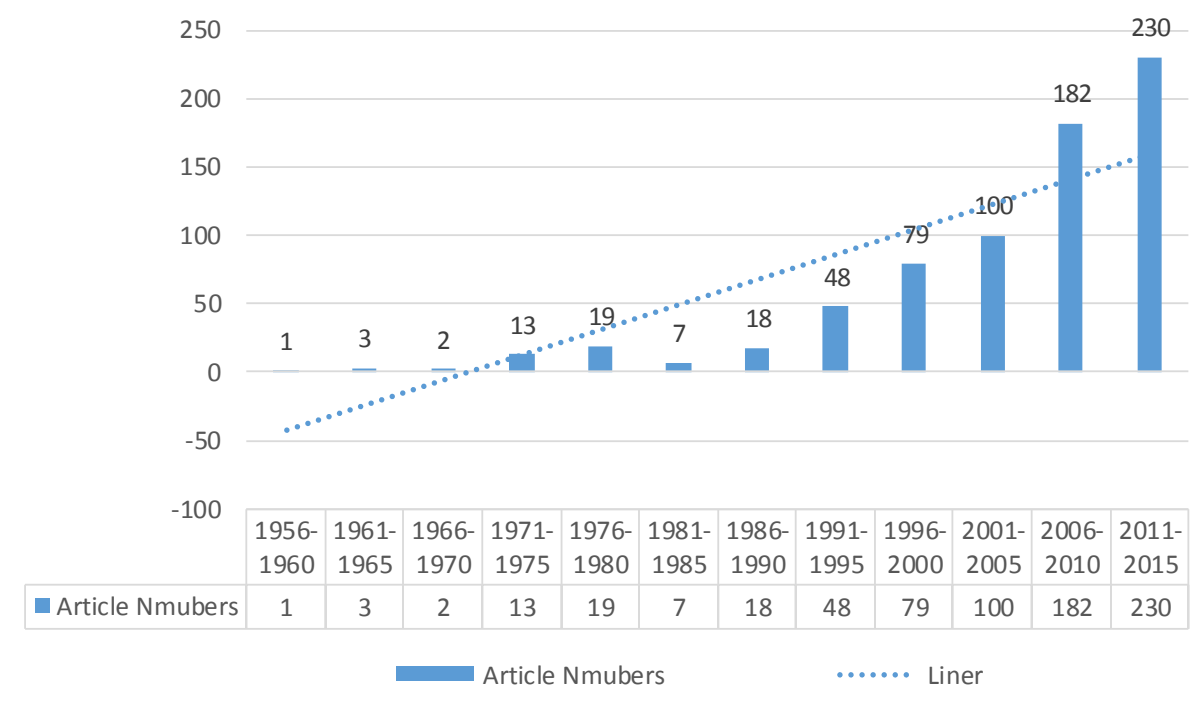

Figure 1. Statistic of REITs articles numbers from 1956-2015. 


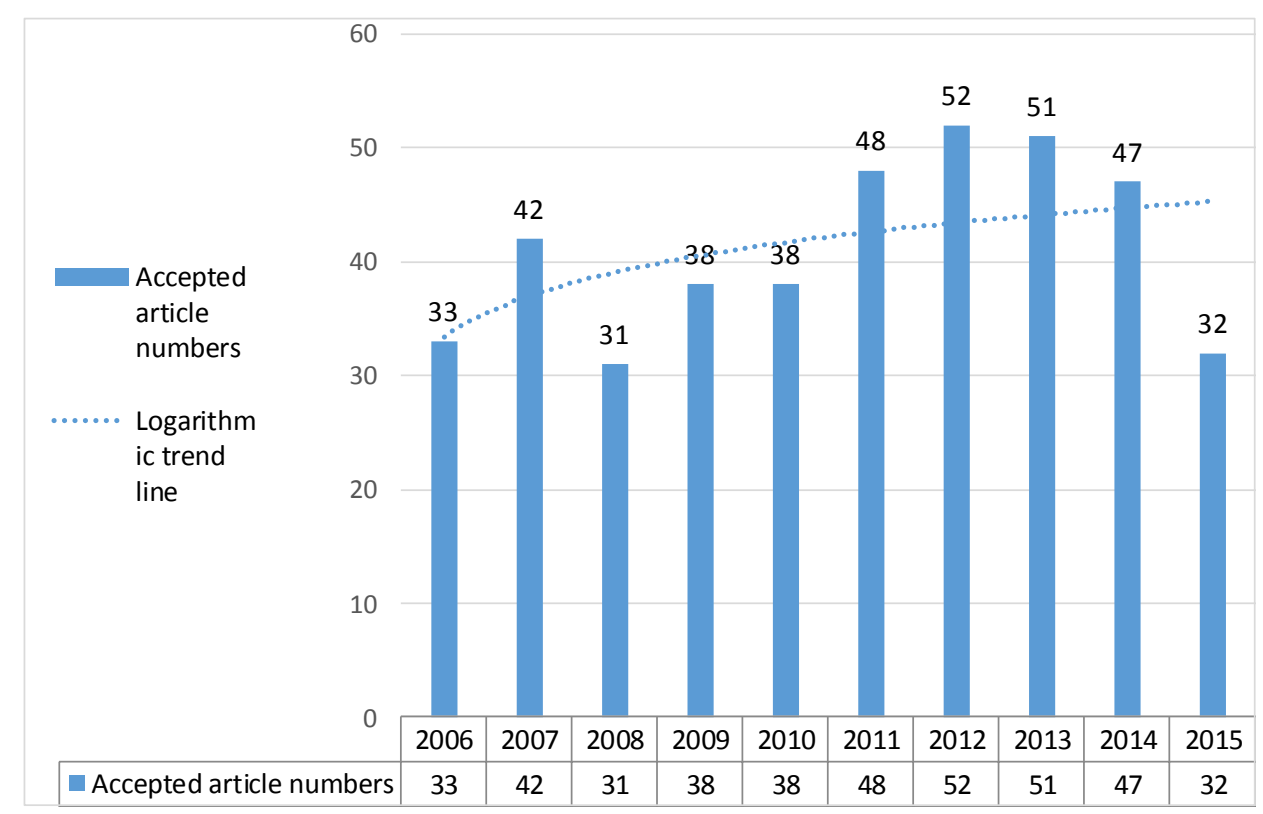

Figure 2. The quantitative characteristic of REITs research from 2006-2015.

\subsection{Important Academic Journals}

Academic journals show the results of research areas, and it has played a role of publicity. The contents of academic journals mainly focus on forms like original research, review articles, book reviews, articles and other forms. Doing statistical analysis towards articles' journal sources, we can emphasize the important journals of REITs field, and have a preliminary understanding of biased research emphasized by the Institute. This article statistics those journals which had published more than 10 articles included by WOS Core Collection. The results are shown in Table 2.

First, in the terms of the published articles numbers, there are 459 articles in total in 9 magazines of chart 2, accounting for 65.38 percent of the total number of the articles. Through theses 9 magazines, we find that REITs study has higher clustering than other fields, most parts of REITs research papers were published on the real estate magazine. There were 217 articles published on the Journal named Real Estate Finance and Economics, accounted for 30.91 percent of the total article. In addition, this paper also counts the five year impact factor of magazines we have mentioned above. Impact factor is a data published by journal citation reports by Thomson Reuters group, it has already became a evaluating indicator received by researchers worldwide. Impact factor is not only an indicator to measure of the usefulness and the significance of the journal, but also the important indicator to measure the academic level and the quality of the articles. In these 9 magazines mentioned above, except that we didn't find the impact factor of the journal real estate review and journal of taxation, the five year impact factor of the rest of 7 magazines were all beyond 0.5 .

Last part of the quantitative analysis, we recognized these magazines could classified into three types according to their different areas of focus. The first type of these academic journals focus on real estate research, and it is the type of magazine that publishing most REITs study articles. These magazines are mainly include Journal of real estate finance and economics. Real estate economic and real estate review, these magazines' impact factors were all beyond 1 , it mainly focus on the subject contains of real estate, urban economics, housing, regional science and public policy and etc. The second type of REITs magazine was financial and economic news magazine including Forbes, Fortune. These journals usually issued in a short period of time (generally every two weeks ), it often have a higher circulation than the general academic journals, these journals focus on a wide range of areas, including financial, industrial, investment and marketing, technology, communications, science and law and etc. The third type of REITs magazines have the less numbers of REITs study articles than the first and the second type of magazine we have mentioned above. These magazines are mainly a number of macroeconomic research journals, REITs research is only a small part of its research, these journals including International Journal Consumer Studies, Journal of Portfolio Management and etc. 
Table 2. The source of REITs research journal article.

\begin{tabular}{cccc}
\hline Journal Name & 5-Year Impact Factor of Journal & Papers & $\begin{array}{c}\text { The Proportion of the Total } \\
\text { Number of Papers }\end{array}$ \\
\hline Journal of Real Estate Finance and Economics & 1.014 & 217 & $30.91 \%$ \\
Real Estate Economics & 1.329 & 88 & $12.53 \%$ \\
Forbes & 0.502 & 69 & $9.83 \%$ \\
Fortune & 0.143 & 23 & $3.28 \%$ \\
Real Estate Review & No Results Found & 17 & $2.42 \%$ \\
International Journal of Consumer Studies & 1.32 & 13 & $1.85 \%$ \\
Journal of Portfolio Management & 0.576 & 11 & $1.57 \%$ \\
Economic modeling & 0.887 & 10 & $1.57 \%$ \\
Journal of Taxation & Not Available & $1.42 \%$ \\
\hline
\end{tabular}

\subsection{Cooperation Characteristic}

From the current international trend of papers publication, authorship situation had moving to the direction that there are two people and more than two people were the paper's author. As Chinese scholars J. Hou and X. Hu put in them research in 1994, they analyzed 2479 papers of the National Academy of Sciences published in 1994 and found that there were only 70 papers were published by an single author, only accounted for $2.9 \%$ of the whole articles in 1994, and the co-authored papers accounted for 97.1\% [11]. In this paper, the analysis of the degree co-authors characteristic of the REITs field were mainly from the degree of co-authors and international cooperation these two aspects.

In the first place, this paper using the degree of co-author indicator by Sunbramanyamk put in his paper named bibliometric studies of research collaboration in 1983, this is aim at analyzing the cooperation relationship in REIT research [12].

$$
\begin{gathered}
\mathrm{DC}=\frac{N-f_{1}}{N} \times 100 \% \\
\mathrm{CI}=\sum_{j=1}^{k} j f_{j} / N
\end{gathered}
$$

As we can from the formula above, DC was the percentage of the co-author relationship, it means the proportion of co-author articles in all the papers we have been searched, it aims at reflect the spans of cooperation in research. CI was the degree of co-author relationship, which was means the author numbers per articles in a certain period of time, it aims at reflect the depth of the cooperation in research. $N$ was the total number of articles, in this paper, $N$ was $702, f_{1}$ was the number that written by only a single author, $f_{j}$ represent all the articles that the author number equals to $j, K$ represent the maxim of co-authors numbers in one paper of these 702 articles. We put these 702 articles into EndNote to analyze the situation of the co-authors in REITs research. According to our statistics by EndNote, from 1958 to 2015, there were 184 articles that was written by a single author, accounted for 26.2 percent of the total article numbers, that means from the time 1958 to 2015, the degree of coauthor in REITs research was about 73.8 percent, about $73.8 \%$ of REITs study were developed by cooperation works, rather than a single author. And from 1958 to 2015 this period of time, CI equals to 2.27, that means, every REITs articles was written by the number of 2.27 author.

In order to research the REITs study cooperation relationship between countries, this paper painted the merged network of REITs research with the help of CiteSpace developed by Dr. Chen of Drexel Uni. We put these 702 articles into CiteSpace software, set parameters as follows: selected the time slicing as 2006-2015, and its year per slice equals to 1 . Selecting the node types as country, and set the threshold as top $n$ per slice, $n$ equals to 50 . With these parameters, painting the merged network of countries as what was shown in Table 2, the details shown in Figure 3. 
Figure 3. The merged network of cooperate author's countries.

As we can see from Table 2, the merged network was consisting of 31 countries and 25 linkages between nodes. From the frequency of citation country, the most cited country in REITs research is USA, which include 210 articles, far more than other countries, it also represent that US has the domain advantage in REITs research in worldwide. The second most cited country was China, although China developed REITs a little bit late than other counties (China's first public offering REITs was started in July of 2015), but it has produced 48 articles of REITs in Web of Science Core Collection database, accounted for $6.8 \%$ in the total published articles numbers, also, from this statistics, we could also conclude that China's determination in developing REITs. Countries like Australia, German and Japan and England were close behind in cited frequency.

The nodes in purple color stands for this node are the key node. From Table 3, we could conclude that England has the biggest centrality than other countries (districts), followed by France, German, USA, Australia, Singapore and etc. The measurement of centrality was related the number of times that countries or institution appeared in the same article, the higher the centrality was, the more active role the author (country or institution) would play, the more cooperation role it would play [13]. From the view of centrality, Britain, the United States, German, Singapore, these countries dominate REITs research front. Which shows that these countries not only published more REITs articles than other countries, but also reflects that these countries played a vital role in the international REITs cooperation. Within these countries which has the articles more than 10, Holland and South Korea's centrality was 0, which means the REITs research in these countries were cooperated by domestic scholars, has less communication with the outside countries REITs researchers.

\section{Key Literature Analysis}

Thomas Kuhn, the famous U.S. physicist and philosopher of science, once said in his book The Structure of Scientific Revolutions (1962), "paradigm is an acknowledged model or pattern, and the paradigm shift refers to the changes on basic hypothesis of basic theory in the science category, and these "changes" during revolutions in science often leads to new paradigms" [14]. CiteSpace, the software deeply influenced by Kuhn's The Structure of Scientific Revolutions, consider scientific study should focus on paradigm, paradigm shift, and to explore the turning points which plays a key role in paradigm shift. In scientific research, these turning points often show as sets of key nodes literatures. Key nodes literature usually refers to the literature which put forward the important theory or innovative conceptions in its relative research field. Also, these key nodes literature was most likely to lead to a new research frontier or research hot topics. In the mapping knowledge domain, the key 
Table 3. The frequency and centrality of cooperate author’s countries.

\begin{tabular}{ccc}
\hline Countries & Frequency & Centrality \\
\hline USA & 210 & 0.23 \\
China & 48 & 0.08 \\
Taiwan & 32 & 0.00 \\
Singapore & 19 & 0.16 \\
Netherlands & 17 & 0.00 \\
Australia & 16 & 0.16 \\
Canada & 16 & 0.09 \\
England & 14 & 0.29 \\
Germany & 11 & 0.24 \\
South Korea & 11 & 0.00 \\
\hline
\end{tabular}

node literature often acts as nodes which connects two or more different clusters and it often have a higher relative centrality and citations frequency. In general, the higher centrality the key nodes have the more important "intermediary" effect it will be played in the knowledge network.

702 literatures about REITs were imported into the CiteSpace, which are the total number about REITs in the Web of Science Core Collection. Specific parameters are set as follows: setting time slicing as 2006-2015, years per slice as 1 , theme sources as title, abstract, author keywords, term type as citied reference, selection criteria as top $1 \%$ per slice. Sorting out the cited literatures of each time slice according to theirs cited frequency, and keeping the top $1 \%$ of literature as a node. Then set the value of threshold in the article labeling column as 30 in the mapping knowledge domain, thus, only the literature which the cited frequency is over 30, the title and author name will be displayed. The knowledge map was as shown in Figure 4 and Table 4.

In Figure 4, we can see the co-citation relationship between literatures in the field of REITs. This map only shows the literatures and author's name which theirs cited frequency are more than 30 times. In the knowledge map, the key literature was shown as purple nodes, that means the node's centrality are larger than 0.1 . We ranked the top 5 key literatures from most to least according to theirs cited frequency (theirs cited frequency are all larger than 30), the result is as shown in Table 4.

From the knowledge map and the table aboved, we can see that the article Common Risk-factors in the Returns on Stocks and Bonds by Eugene F. Fama has the highest cited frequency and centrality, which was published in Journal of Financial Economics in February 1993 [15]. According to the centrality of the key nodes in the network knowledge map, the centrality of Eugene's article is as high as 0.32, much higher than the standard of 0.1 , which can be considered to be the centrality node. What's more, it is worth mentioning that this article has been cited as high as 3405 times in WOS Core Collection.

Eugene F. Fama is now teaching at the Booth School of Business in the University of Chicago. He majors in modern portfolio theory and asset pricing theory. Eugene is famous for putting forward the efficient market hypothesis and it was worth mentioning that Eugene was awarded the Nobel Economics Prize in 2013 for his contribution in economic filed. In this 54-page empirical analysis paper, Eugene developed his former three-factor model in stocks market, which was proposed in 1992, and promoted it to the bonds market (including corporate bonds and federal bonds). In this paper, he pointed out there are five risk factors in the returns of stocks and bonds market.

Three risk factors that will influence the stock market are as follows: first one is the overall market factor, and the second one is factors which related to firm sizes. The last one is the factors which related to book-to-market equity. While, the two risk factors of bond market are factors related to maturity and factors related to default risks. Eugene thought that there is a close contact between bond markets and stock markets, and stock returns will have shared the fluctuations due to the volatility of bond market.

Eugene's article not only paved the way for the integration of REITs and the stock \& bond markets, but also laid a foundation of many following papers. For example, the article written by David. C. Ling, titled The Inte- 


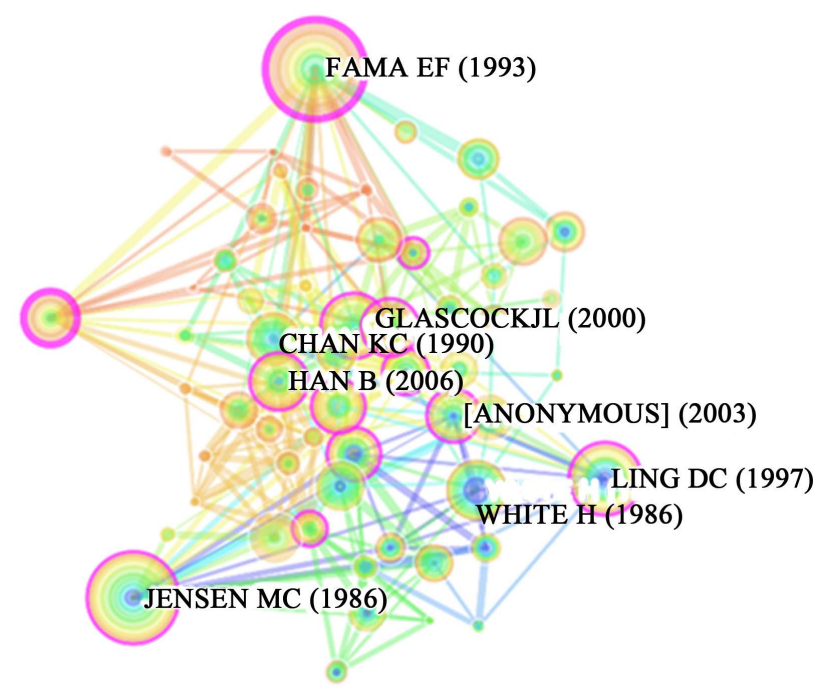

Figure 4. A 244-node merged network of cited reference in REITs research field.

Table 4. The top 5 key literature according to cited frequency sort.

\begin{tabular}{cccc}
\hline Freq & Centrality & Author & Cited reference \\
\hline 47 & 0.32 & Eugene F. Fama & Common Risk-factors in the Returns on Stocks and Bonds \\
46 & 0.13 & Michael C. Jensen & Agency Costs of Free Cash Flow, Corporate Finance, and Takeovers \\
36 & 0.11 & DAVID C. LING & $\begin{array}{l}\text { Valuation uncertainty, institutional involvement, } \\
\text { and the underpricing of IPOs: The case of REITs }\end{array}$ \\
35 & 0.18 & JOHN L. GLASCOCK & Further Evidence on the Integration of REIT, Bond, and Stock Returns \\
32 & 0.11 & Anonymous & $\begin{array}{c}\text { Key rulings affect REIT reimbursement arrangements } \\
\text { and the ownership look-through rule }\end{array}$ \\
\hline
\end{tabular}

gration of Commercial Real Estate Markets and Stock Markets, published in the journal Real Estate Economics in 1999. David's paper used the multifactor asset pricing models to discuss the problem whether the commercial real estate market (including exchange-traded and non-exchange-traded) is integrated with stock markets or not. Soon after, Peterson. J. D. and Hsieh. C. H. developed the applicability of this theory [16], theirs paper Do Common Risk Factors in the Returns on Stocks and Bonds Explain Returns on REITs? was published on the journal of Real Estate Economics in 1999. Through the empirical analysis of data from 1976 to 1992, they found that the returns of mortgage REITs and equity are influenced by factors was mentioned by Eugene in 1993.

According to the cited frequency, the second article is Michael C. Jensen's Agency Costs of Free Cash Flow, Corporate Finance, and Takeovers on American Economic Association, published in 1986. Michael C. Jensen is a master scholar across two fields, the economics and corporate finance \& management. Not only have a pivotal position in capital market theory, Michael also has made pioneering work in corporate governance field and capital structure theory. Meanwhile, he is one of the founders of agent economics as well.

In this article, Michael C. Jensen pointed out that the widespread existence of agency cost could lead to a relationship fraught with conflicting interests between shareholders and managers. It is worth mentioning that the conflicts of interest between shareholders and managers are especially severe when enterprise having a free cashflow. Also, in this paper, he explained the benefit of debt in cutting down agency cost of free cash flow (FCF), and pointed out how debt could substitute for dividends. Last but not the least, this paper believes that enterprise will assume more loss when they choosing diversification strategy instead of takeover or expanding. This point of view is used in REITs and other fields, explaining why REITs choose to expand in purchasing new real estate projects, instead of developing other business through the redundant cash flow. Many following study of REITs are based on this study, for example, the article, Competition, Auctions \& Negotiations in REIT Takeovers, published on Journal of Real Estate Finance and Economics by Mulherin. J. H and Womack. K. S, is 
the extension of this idea. In this paper, they use hand-collected data from SEC merger filings to explain the benefit of mergers and acquisitions for REITs [17].

According to Table 4, the third paper is Valuation uncertainty, institutional involvement, and the underpricing of IPOs: The case of REITs, published in Journal of Financial Economics in 1997 by DAVID C. Ling [18]. David C. Ling is the professor of University of Florida, majors in real estate and finance, and his research fields include the differences \& similarities between REITs and stocks and bonds, private REITs and public REITs, the influencing factors of REITs' return, etc.

David pointed out in the paper mentioned above, the IPO of REITs in 1980s is different from other operating companies. David believes that in 1980s, the issue price of the listed REITs often much overestimated at first and after a period of time, it would go stagnant. On the contrary, he believes that in 1990s, REITs issue price were always underestimated at first, and then, after listing, appeared different amplitude increases. He attributed this phenomenon to the larger uncertainty of market valuation, and the changes of institutional participation in the REITs IPO process.

After David, there has been an increasing attention to the problem of REITs' IPO, and this question has gradually become one of the hot topic of REITs research. Since 2000, many high cited articles were focus in this research hotspot. Such as The pricing of property trust IPOs in Australia by Dimovski W. and Brooks R., published on Journal of Real Estate Finance and Economics, it explained the IPO pricing question of REITs by forecast profit distributions and market sentiment [19]. Chan S. H., Wang K and Yang J., these three Taiwan scholars published their work, IPO Pricing Strategies with Deadweight and Search Costs published on Journal Of Real Estate Research, and they put forward a model to provide a complementary explanation to the wellknown pricing puzzle [20], which was based on assessing the investor's possible post-search outcomes.

From the co-citation network in Table 4, on the basis of the cited frequency, we can find that the 4th highest literature is Further Evidence on the Integration of REIT, Bond, and Stock Returns by John L. Glascock, Lu, C. $\mathrm{L}$ and So, R. W. There are many linkages between this article and the literature of Eugene F. Fama that means the co-citation frequency is relative high [21].

Glascock inherited and developed the ideas of Eugene F. Fama, by using the method of co-integration analysis and vector autoregressive model, he explored the relationship among these financial products, the REITs, bonds and stocks. His conclusion is that we cannot simply equate REITs markets with bonds or stocks markets, they are different. He thought since the structural changed in the early1990s, REITs products were more like stocks, instead of bonds [22]. In this article, he also developed the opinion of Michael on diversification, he suggested that the benefits of diversification by including REITs in multi asset portfolios diminish after 1992.

\section{Discussion}

The research of REITs began from 1960s, and there are thousands of researcher devote themselves into REITs research until this present day. Although there are so much researchers studying REITs today, but less researchers focus on the theory of REITs research. Chinese researchers Yu, B. T. \& Xia, Q. S. had published there articles Study on the pattern of the Real Estate Investment Trusts in China, they give us a deep insight into the mature patterns of REITs in US and other REITs countries and analyses the latest experiments of Chinese domestic trust [23]. But, these scholars only gather 5 references to prove their research, also, this articles pay more attention to the patterns of REITs development, not the REITs literature. This research tries to find the patterns of REITs research, in order to provide inspiration for REITs researchers.

The follow-up studies of REITs could carry out from different perspective. Firstly, REITs research could pay more attention to real estate portfolio choice, namely on choosing investment object, current real estate investment trust fund investment's targets are mainly concentrated in retail business, office building, residence, etc., while for other real estate, such as industrial real estate, resort real estate and some other real estate which the cash flow also steady, the attention on them are not a lot. Secondly, countries that have not been carrying on REITs or REITs development experience is weak, such as China, may focus on following the main mechanism of REITs and scholars research achievements, which more practical measures and suggestions of REITs development can be put forward for these countries.

\section{Conclusion}

In this paper, we developed a series of analysis towards the basic features of REITs research, including the 
quantity characteristics, cooperation characteristics etc. And we mainly discussed 4 important turning points literatures of REITs research. The main conclusions were as follows: First, great breakthrough of REITs research literatures were all appeared in the 1990s, however, after entering 21st century, REITs research hadn't made much progress. Second, the focus of REITs field had gradually transferred from comparing the similarities and differences between REITs and other investment to the REITs product itself. Third, the REITs knowledge relied on finance and economics to a great extent. The largest number of references was classic economics research, while the classic literature of real estate and the land resource were rarely mentioned. Nowadays, REITs still focused on trust rather than the real estate. Fourth, it was the United States that first went into the field of REITs research, and received the most quantity of the research result. In addition, the United States had become the center of international REITs research and led the study of REITs in other countries.

\section{References}

[1] Tang, S. (2014) International Comparison and Enlightenment of REITs. Chinese Finance, 13, 74-75.

[2] Block, R.L. (2008) Investing in REITs. China Citic Press, Beijing, 8-23.

[3] Block, R.L. (2008) Investing in REITs. China Citic Press, Beijing, 75-76.

[4] Christopher, D. (2005) An Age of Transition? Economy and Society in England in the Later Middle Ages. Oxford, 615.

[5] Yan, L.G. (2011) Visual Analysis of Visual Information Retrieval. Modern Intelligence, 3, 122-126.

[6] Pritchard, A. (1969) Statistical Bibliography, an Interim Bibliography, Clearing House for Federal Scientific and Technical Information. Springfield, 112-124.

[7] Chen, C. (2006) CiteSpace II: Detecting and Visualizing Emerging Trends and Transient Patterns in Scientific Literature. Journal of the American Society for Information Science and Technology, 57, 359-377. http://dx.doi.org/10.1002/asi.20317

[8] Chen, C. (2004) Searching for Intellectual Turning Points: Progressive Knowledge Domain Visualization. Proceedings of the National Academy of Sciences of the United States of America, 101, 5303-5310. http://dx.doi.org/10.1073/pnas.0307513100

[9] Watters, F.L. (1958) Value of Cotton and Jute Flour Bags in Reducing Infestation by the Hairy Spider Beetle, PtinusVilliger (REIT). Cereal Chemistry, 35, 317-321.

[10] Giacomini, E., Ling, D.C. and Naranjo, A. (2015) Leverage and Returns: A Cross-Country Analysis of Public Real Estate Markets. The Journal of Real Estate Finance and Economics, 51, 125-159. http://dx.doi.org/10.1007/s11146-014-9489-5

[11] Hou, J. and Hu, X.Y. (1997) The Development Trend of the Research on the Cooperation of the 90's from the Scientific and Technical Papers. Journal of Intelligence, 16, 313-317.

[12] Subramanyam, K, (1983) Bibliometric Studies of Research Collaborate: A Review. Journal of Information Science, 6, 33-38. http://dx.doi.org/10.1177/016555158300600105

[13] Persson, O. (1994) The Intellectual Base and Research Fronts of JASIS 1986-1990. Journal of the American Society for Information Science, 45, 31-38. http://dx.doi.org/10.1002/(SICI)1097-4571(199401)45:1<31::AID-ASI4>3.0.CO;2-G

[14] Thomas, S.K. (2012) The Structure of Scientific Revolutions. University of Chicago Press, Chicago, 4-8.

[15] Fama, E.F. (1993) Common Risk-Factors in the Returns on Stocks and Bonds. Journal of Financial Economics, 33, 3-56.

[16] Ling, D.C. and Naranjo, A. (1999) The Integration of Commercial Real Estate Markets and Stock Markets. Real Estate Economics, 27, 483-515. http://dx.doi.org/10.1111/1540-6229.00781

[17] Mulherin, J.H. and Womack, K.S. (2015) Competition, Auctions \& Negotiations in REIT Takeovers. The Journal of Real Estate Finance and Economics, 50, 151-180. http://dx.doi.org/10.1007/s11146-013-9447-7

[18] Ling, D.C. and Ryngaert, M. (1997) Valuation Uncertainty, Institutional Involvement, and the Underpricing of IPOs: The Case of REITs. Journal of Financial Economics, 43, 433-456.

[19] Dimovski, W. and Brooks, R. (2006) The Pricing of Property Trust IPOs in Australia. The Journal of Real Estate Finance and Economics, 32, 185-199. http://dx.doi.org/10.1007/s11146-006-6014-5

[20] Chan, S.H., Wang, K. and Yang, J. (2009) IPO Pricing Strategies with Deadweight and Search Costs. Journal of Real Estate Research, 31, 481-542.

[21] John, L.G., Lu, C.L. and So, R.W. (2000) Further Evidence on the Integration of REIT, Bond, and Stock Returns. The 
Journal of Real Estate Finance and Economics, 20, 177-194.

[22] Capozza, D.R. and Shilling, J.D. (2005) Introduction to the Special Issue. Real Estate Economics, 33, 1-3. http://dx.doi.org/10.1111/j.1080-8620.2005.00109.x

[23] Yu, B.T. and Xia, Q.S. (2006) Study on the Pattern of the Real Estate Investment Trusts in China. Proceedings of 2006 International Conference on Construction \& Real Estate Management, 2, 362-364. 